\title{
Flexural Properties, Morphology and Bond Strength of Fiber-Reinforced Posts: Influence of Post Pretreatment
}

\author{
Neilor Mateus Antunes BRAGA \\ Aline Evangelista SOUZA-GABRIEL \\ Danielle Cristine Furtado MESSIAS \\ Fuad Jacob Abi RACHED-JUNIOR \\ Camila Fávero OLIVEIRA \\ Ricardo Gariba SILVA \\ Yara T. Corrêa SILVA-SOUSA
}

Dental School, University of Ribeirão Preto, Ribeirão Preto, SP, Brazil

\begin{abstract}
The aim of this study was to assess the influence of surface pretreatments of fiber-reinforced posts on flexural strength (FS), modulus of elasticity (ME) and morphology of these posts, as well as the bond strength (BS) between posts and core material. Fifty-two fiber posts (smooth and serrated) were assigned to 4 groups $(\mathrm{n}=13)$ : no treatment (control), 10\% hydrogen peroxide (HP) for 10 min (HP10), 24\% HP for $1 \mathrm{~min}$ (HP-24) and airborne-particle abrasion $\left(\mathrm{Al}_{2} \mathrm{O}_{3}\right)$. To evaluate $\mathrm{FS}$ and $\mathrm{ME}$, a 3-point bending test was performed. Three posts of each group were examined by scanning electron microscopy. Composite resin was used as the core build-up and samples were sectioned to obtain microtensile sticks. Data were analyzed by ANOVA and Tukey's test $(\alpha=0.05)$. For FS, significant differences were observed between posts type and surface pretreatment $(\mathrm{p}<0.05)$, with the highest means for the smooth posts. $\mathrm{Al}_{2} \mathrm{O}_{3}$ provided higher FS than HP-24. $\mathrm{Al}_{2} \mathrm{O}_{3}$ promoted higher ME than HP-24 and control. SEM images revealed partial dissolution of the resin matrix in all treated groups. The smooth posts had higher BS and FS than serrated posts $(\mathrm{p}<0.05)$. Mechanical properties of the glass fiber posts and the bond strength between posts and composite material were not altered by the surface treatments, except for airborne-particle abrasion that increased the post elastic modulus.
\end{abstract}

Key Words: aesthetics, dental practice, fiber post.

\section{INTRODUCTION}

Glass fiber-reinforced posts have been proposed for the restoration of endodontically treated teeth due to the esthetic coloration and favorable biomechanical properties (1-3). The modulus of elasticity of glass fiber posts is almost similar to that of tooth structure and resinous materials (3), thus it can provide optimal stress distribution and reduce the risk of root fracture.

Chemical and mechanical treatments of the post surface as well as changes in the matrix of the posts appear to influence the bond strength between resin materials and fiber posts (4-10). The post matrix, consisting of epoxy resin, has no functional group able of reacting with the silane and the effectiveness of the adhesion may be compromised $(8,11)$. Surface post treatments with subsequent silanization are proposed to allow better interaction with the resin cements and enhance chemical and micromechanical bonding (12).

Some techniques are proposed for conditioning the fiber post surface, such as hydrogen peroxide (HP) solution (12-14) and airborne-particle abrasion (7,1517). It is speculated that HP is able to degrade the epoxy resin matrix and expose the glass fibers. The use of more concentrated products with less exposure time could improve the adhesion and optimize the clinical time (12). Airborne-particle abrasion produces a roughened surface as a result of the high-speed impact of abrasive particles, enabling better interaction with the resin cement, but the roughened surface may produce surface damage which, 
in turn, reduces the strength of the post (7).

Surface pretreatment of posts is expected to increase the chemical and mechanical bond between the composite core material and post, but the best method has not yet been established. Furthermore, few studies evaluated the effect of conditioning methods on the morphology and mechanical properties of posts. The aims of this study were 1 . to assess in vitro the effect of surface treatments of two glass fiber posts (smooth and serrated) with 10\% HP for 10 min (HP-10), 24\% HP for 1 min (HP-24) and airborne-particle abrasion $\left(\mathrm{Al}_{2} \mathrm{O}_{3}\right)$ on flexural strength (FS), modulus of elasticity (ME) and morphology of these posts; 2 . to evaluate the bond strength (BS) between fiber posts and composite core material.

\section{MATERIAL AND METHODS}

Two types of glass fiber-reinforced posts were selected: 1) Reforpost (Angelus, Londrina, PR, Brazil) and 2) White Post DC (FGM, Joinville, SC, Brazil). Posts from Reforpost system are parallel, serrated and have a 1.5-mm diameter (corresponding to the \#3). Posts from White Post DC system have dual shape and diameter of $1.6 \mathrm{~mm}$ in the cylindrical part (corresponding to the \#1).

Fifty-two posts of each type were cleaned with $70 \%$ ethanol, dried and distributed randomly into 4 groups ( $\mathrm{n}=13)$, according to the type of surface treatment: A - no treatment (control, ST); B - 10\% HP (Dynamics, São Paulo, SP, Brazil) for 10 min (HP-10); C - 24\% HP (Dynamics) for $1 \mathrm{~min}$ (HP-24) and D - airborne particles abrasion (Polidental LTDA, Cotia, SP, Brazil) $\left(\mathrm{Al}_{2} \mathrm{O}_{3}\right)$.

In groups $1 \mathrm{~B}$ and $2 \mathrm{~B}$, the posts were immersed in $2 \mathrm{~mL}$ of $10 \% \mathrm{HP}$ for $1 \mathrm{~min}$ and then immersed in four baths with $3 \mathrm{~mL}$ of distilled water, remaining $1 \mathrm{~min}$ in each. They were then subjected to the final wash with $3 \mathrm{~mL}$ of distilled water and air-dried.

In groups $1 \mathrm{C}$ and $2 \mathrm{C}$, the posts were immersed in $2 \mathrm{~mL}$ of $24 \% \mathrm{HP}$ for $10 \mathrm{~min}$, immersed in four baths with $3 \mathrm{~mL}$ of distilled water for $1 \mathrm{~min}$ each, subjected to a final wash with $3 \mathrm{~mL}$ of water distilled and air-dried.

In $1 \mathrm{D}$ and $2 \mathrm{D}$ groups, the posts were abraded with aluminum oxide particles $(50 \mu \mathrm{m})$, using a microjet system (Bio-Art, São Carlos, SP, Brazil) at a distance of $10 \mathrm{~mm}$ from the specimen, $90^{\circ}$ inclination and 2 bar pressure. The posts were demarcated into 4 parts and each was sprayed for $3 \mathrm{~s}$, a total of $12 \mathrm{~s}$. Subsequently, the posts were washed with distilled water and air-dried in the same sequence of groups B and C.

\section{Three-Point Bending Flexural Test}

For this test, the standards suggested by DIN-EN 843-1 were followed. Five posts of each group were stored at $37^{\circ} \mathrm{C}$ for $48 \mathrm{~h}$. To standardize the post shape, only the cylindrical portion of White Post DC system (smooth) was used. Each post diameter was measured at 5 different points with digital caliper (Digimess; Precision Gaging Shiko Ltd., China). The mean measures of each post were recorded and tabulated for subsequent calculations. The flexural test was carried out in universal testing machine (Instron 4444), following ISO 178 standard specifications. A metallic device attached to Instron machine was developed for this test. This device fixed the distance between the center support points in $8 \mathrm{~mm}$ and fits the dimensions of the sample. The load cell was applied perpendicular to the post long axis with a crosshead speed of $0.5 \mathrm{~mm} / \mathrm{min}$ until fracture. Post flexural strength $\left(\sigma_{\mathrm{f}}\right)$ was calculated using the following equation: $\sigma_{\mathrm{f}}=3 \mathrm{~F}_{\max }$ $\mathrm{L} / 2 d^{2}$, where, $\mathrm{F}_{\max }$ is the maximum load in $\mathrm{N}, \mathrm{L}$ is the distance between the support points in $\mathrm{mm}$ (standardized in $8 \mathrm{~mm}$ ) and $\mathrm{d}$ is the post diameter.

\section{Modulus of Elasticity}

From the values obtained by 3-point bending test, the modulus of elasticity $\left(\mathrm{E}_{\mathrm{f}}\right)$ were calculated by the following equation: $E_{f}=S 4 L^{3} / 3 d^{4}$, where $S$ is the stiffness, $\mathrm{L}$ is the distance between the support points in $\mathrm{mm}(8 \mathrm{~mm})$ and $\mathrm{d}$ is the diameter of the post. Therefore, to obtain the $\mathrm{E}_{\mathrm{f}}$ value, it was previously calculated value of $S$ by the equation: $\mathrm{F}=\mathrm{S} / \mathrm{D}$, where $\mathrm{F}$ is the maximum load value in Newton and $\mathrm{D}$ is the deflection value (in $\mathrm{mm}$ ).

\section{SEM Analysis of Posts Surface}

Three posts of each groups were cleaned in a ultrasonic bath (3L Alpha Plus; Ecel, Ribeirão Preto, SP, Brazil), immersed in $95 \%$ ethanol, air-dried and stored at $37^{\circ} \mathrm{C}$ for $1 \mathrm{~h}$. Gold-palladium sputter coating was carried out (Denton Desk II; Denton Vacuum LLC, Moorestown, NJ, USA) and the posts were examined with a scanning electron microscope (JSM-5410; JEOL Ltd., Tokyo, Japan). SEM micrographs were done with standardized magnifictaion of $\times 500$ and were analyzed qualitatively.

\section{Bond Strength Test}

The core was filled with self-curing resin (Core- 
Flo; Bisco Inc., Schaumburg, IL, USA) using a silicone mold (Aquasil Ultra LV; Dentsply, Milford, DE, USA) obtained from matrix formed by post fiber and acetate plates. Five posts of each group were prepared for microtensile test. A silane layer (Bis-Silane; Bisco Inc.) was applied, after $60 \mathrm{~s}$, as recommended by the manufacturer. The following was done applying a layer of the adhesive system All Bond 2 (D/E Resin; Bisco Inc.) and light-cured for $20 \mathrm{~s}$. The post was inserted inside the silicon mold in the space provided. The composite resin (Core-Flo; Bisco Inc.) was mixed for 15 and inserted in the spaces corresponding to the core using a Centrix syringe (DFL, Rio de Janeiro, RJ, Brazil). After 30 min, the molds were cut and the samples removed and stored in distilled water at $37^{\circ} \mathrm{C}$.

After $48 \mathrm{~h}$, the specimens were fixed in a precision cutting machine (Minitom; Struers, Copenhagen, Denmark). Serial sections were made perpendicular to the long axis of the post using a water-cooled diamond disc (Extec, Enfield, CT, USA). The sections distanced themselves from each other about $1 \mathrm{~mm}$, which allowed obtaining 5 to 6 slices per sample, resulting in $1 \mathrm{x} 1 \mathrm{x}$ $10 \mathrm{~mm}$ sticks-shaped, consisting of resin/post/resin. The sticks (almost 28 for each group) were evaluated in a stereomicroscope (Leica microsytem LTD, Wetzlar, Germany) ( $\times 40)$ and the 15 most homogeneous ones were selected. Those with defects or close to the adhesive interface were discarded.

On each stick, height and width were measured

Table 1. Mean and standard deviation of flexural bond strength (MPa), modulus of elasticity $(\mathrm{GPa})$ and microtensile bond strength to resin $(\mathrm{MPa})$ of fiber-reinforced posts after different surface pretreatments.

\begin{tabular}{lccc}
\hline $\begin{array}{l}\text { Surface } \\
\text { pretreatment }\end{array}$ & $\begin{array}{c}\text { Flexural } \\
\text { strength }\end{array}$ & $\begin{array}{c}\text { Modulus of } \\
\text { elasticity }\end{array}$ & $\begin{array}{c}\text { Bond } \\
\text { strength }\end{array}$ \\
\hline $\begin{array}{l}\text { No treatment } \\
\text { control })\end{array}$ & $687.68 \pm 54.29 \mathrm{ab}$ & $11.36 \pm 0.84 \mathrm{~A}$ & $10.55 \pm 6.97$ \\
$10 \% \mathrm{HP} / 10 \mathrm{~min}$ & $681.18 \pm 78.19 \mathrm{ab}$ & $11.62 \pm 2.19 \mathrm{AB}$ & $16.12 \pm 7.17$ \\
& & & \\
$24 \% \mathrm{HP} / 1 \mathrm{~min}$ & $652.23 \pm 83.92 \mathrm{a}$ & $10.14 \pm 1.14 \mathrm{~A}$ & $19.76 \pm 7.58$ \\
& & & \\
$\begin{array}{l}\text { Airborne-particle } \\
\text { abrasion }\end{array}$ & $730.29 \pm 53.09 \mathrm{~b}$ & $13.43 \pm 1.98 \mathrm{~B}$ & $18.88 \pm 10.93$ \\
\hline
\end{tabular}

Flexural strength: Same lowercase letters indicate statistical similarity $(\mathrm{p}>0.05$; Tukey's critical value $=60.31)$. Modulus of elasticity: Same uppercase letters indicate statistical similarity $(p>0.05$; Tukey critical value $=2.01)$. Bond strength: Same symbols indicate statistical similarity $(\mathrm{p}>0.05$; Tukey's critical value $=5.46)$. with digital caliper (Digimess; Precision Gaging Shiko Ltd.). The samples were fixed individually in a metal device with cyanoacrylate adhesive (Loctite Super Bonder, São Paulo, SP, Brazil). The set was attached to the universal testing machine and were tested with load cell of $50 \mathrm{kgf}$ and crosshead speed of $0.5 \mathrm{~mm} /$ min until breaking. The tensile strength values were transformed into MPa. The samples were analyzed in the stereomicroscope $(\times 40)$ and classified according to the fracture mode: cohesive of the post; cohesive of the resin; adhesive between post and resin; and mixed (presence of cohesive and adhesive fracture in the same specimen).

\section{Statistical Analysis}

Data of flexural strength (MPa), modulus of elasticity $(\mathrm{GPa})$ and the microtensile bond strength $(\mathrm{MPa})$ were analyzed by ANOVA and Tukey test with significance level of 5\%, using SPSS (Statistical Package for the Social Sciences; SPSS Inc., Chicago, IL, USA).

\section{RESULTS}

\section{Three-Point Bending Flexural Test}

Statistical analysis revealed a significant effect on both factors: post type and post pretreatment $(p<0.05)$. No significant difference were verified in the interaction of these factors $(p>0.05)$. Smooth posts (White Post DC) had higher mean values than the serrated posts (Reforpost) $(\mathrm{p}<0.05)$.

Pretreatment with $\mathrm{Al}_{2} \mathrm{O}_{3}$ provided highest values of flexural strength and was statistically similar ( $>>0.05)$ to HP-10 and ST, which were statistically similar $(\mathrm{p}>0.05)$. Fiber posts pretreated with HP-24 showed the lowest flexural strength and did not differ from HP-10 and $\mathrm{ST}(\mathrm{p}>0.05)$. There were significant differences between HP-24 and $\mathrm{Al}_{2} \mathrm{O} 3$ groups $(\mathrm{p}<0.05)$. None of the proposed pretreatments differed from the control group $(\mathrm{p}>0.05)$ (Table 1). 


\section{Modulus of Elasticity}

Analysis of variance showed a statistically significant difference $(p<0.05)$ between the surface treatments of the posts. Factor type of interaction between post and type of treatment showed no statistically significant difference $(\mathrm{p}>0.05) . \mathrm{Al}_{2} \mathrm{O}_{3}$ blasting resulted in higher values of modulus of elasticity and was statistically similar to group HP-10 ( $>0.05)$. HP-24 treatment gave the lowest modulus of elasticity and was not significantly different from ST-10 and HP, which were statistically similar ( $p>0.05)$. Only $\mathrm{Al}_{2} \mathrm{O}_{3}$ increased the modulus of elasticity of the posts in the control group $(\mathrm{p}<0.05)$ (Table 1).

\section{SEM Analysis}

SEM micrographs of serrated and smooth posts revealed that those pretreated with HP $(10 \%$ for 10 $\min$ or $24 \%$ for $1 \mathrm{~min}$ ) and airborne-particles abrasion were different from the untreated posts (control). On untreated posts, for both the smooth and serrated groups, the fibers were shown to be continuous and covered by epoxy resin matrix (Figs. 1A and 1B). Pretreatment with $10 \% \mathrm{HP}$ for $10 \mathrm{~min}$, promoted a slight exposure of the post fibers (arrows), a more evident aspect for the smooth type (Figs. 2A and 2B). Application of 24\% HP for 1 min provided more areas with dissolution of resin matrix and subsequent exposure of the post fibers (arrows). In these groups, some areas with discontinuity of the fibers (circles) were verified (Figs. 2C and 2D). Posts abraded with airborne-particles provided exposed fiber areas (arrows) and discontinuity (circles) post fibers. Some probable remnants of the abrasive particles used during air-abrasion were noted in this group (Figs. 2E and 2F).
Table 2. Failure types (\%) after microtensile bond strength test.

\begin{tabular}{|c|c|c|c|c|c|c|c|c|}
\hline \multirow[b]{2}{*}{ Failure } & \multicolumn{4}{|c|}{ Serrated posts } & \multicolumn{4}{|c|}{ Smooth posts } \\
\hline & NT & $\begin{array}{c}10 \% \\
\mathrm{HP}\end{array}$ & $\begin{array}{c}24 \% \\
\text { HP }\end{array}$ & $\mathrm{Al}_{2} \mathrm{O}_{3}$ & NT & $\begin{array}{c}10 \% \\
\mathrm{HP}\end{array}$ & $\begin{array}{c}24 \% \\
\text { HP }\end{array}$ & $\mathrm{Al}_{2} \mathrm{O}_{3}$ \\
\hline Adhesive & 66 & 40 & 40 & 33 & 53 & 40 & 40 & 33 \\
\hline $\begin{array}{l}\text { Cohesive } \\
\text { (post) }\end{array}$ & 7 & 7 & 0 & 14 & 7 & 0 & 7 & 0 \\
\hline $\begin{array}{l}\text { Cohesive } \\
\text { (resin) }\end{array}$ & 0 & 7 & 7 & 0 & 7 & 0 & 0 & 7 \\
\hline Mixed & 27 & 46 & 53 & 53 & 33 & 60 & 53 & 60 \\
\hline
\end{tabular}

NT: no treatment; $10 \% \mathrm{HP}-10 \%$ hydrogen peroxide after $10 \mathrm{~min} ; 24 \% \mathrm{HP}: 24 \%$ hydrogen peroxide after $1 \mathrm{~min}$; and $\mathrm{Al}_{2} \mathrm{O}_{3}$ : Airborne-particle abrasion.

\section{Bond Strength Test}

Statistical analysis showed significant difference on both factors: post type and post pretreatment $(\mathrm{p}<0.05)$. There was no significant statistical difference $(p>0.05)$ in the interaction of factors. Smooth posts (White Post DC) had higher mean values than the serrated posts (Reforpost) $(p<0.05)$.

ST had the lowest mean
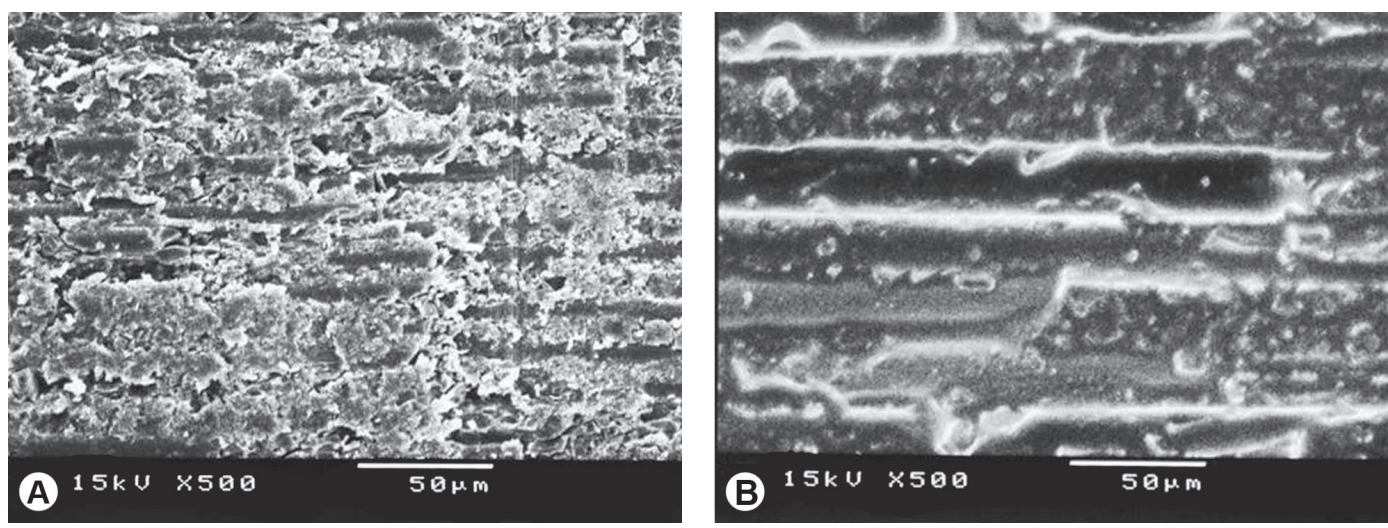

Figure 1. SEM micrographs of the post surfaces with no pretreatment (control) $(\times 500)$. A: serrated post. B: smooth post. Note the continuous fibers and covering the epoxy resin matrix. 
bond strength and was statistically different from the other groups $(\mathrm{p}<0.05)$. Overall, all surface pretreatments increased the microtensile bond strength of the fiberreinforced posts to resin core material (Table 1). The analysis of failures after showed a predominance of adhesive mode in control group and mixed in treated groups of both posts, regardless of the surface pretreatment (Table 2).

\section{DISCUSSION}

Fiber-reinforced posts are preferred than cast posts due to higher post retention, reduced risk of root
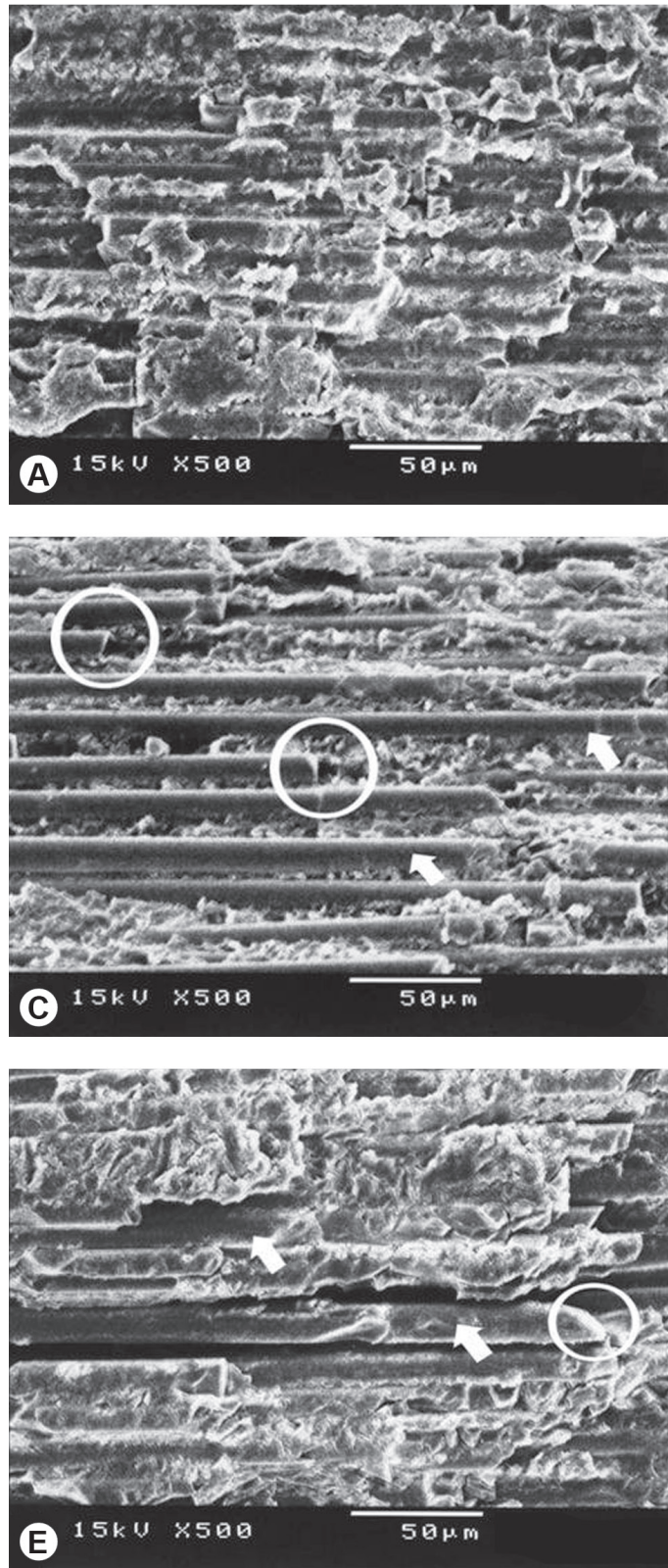
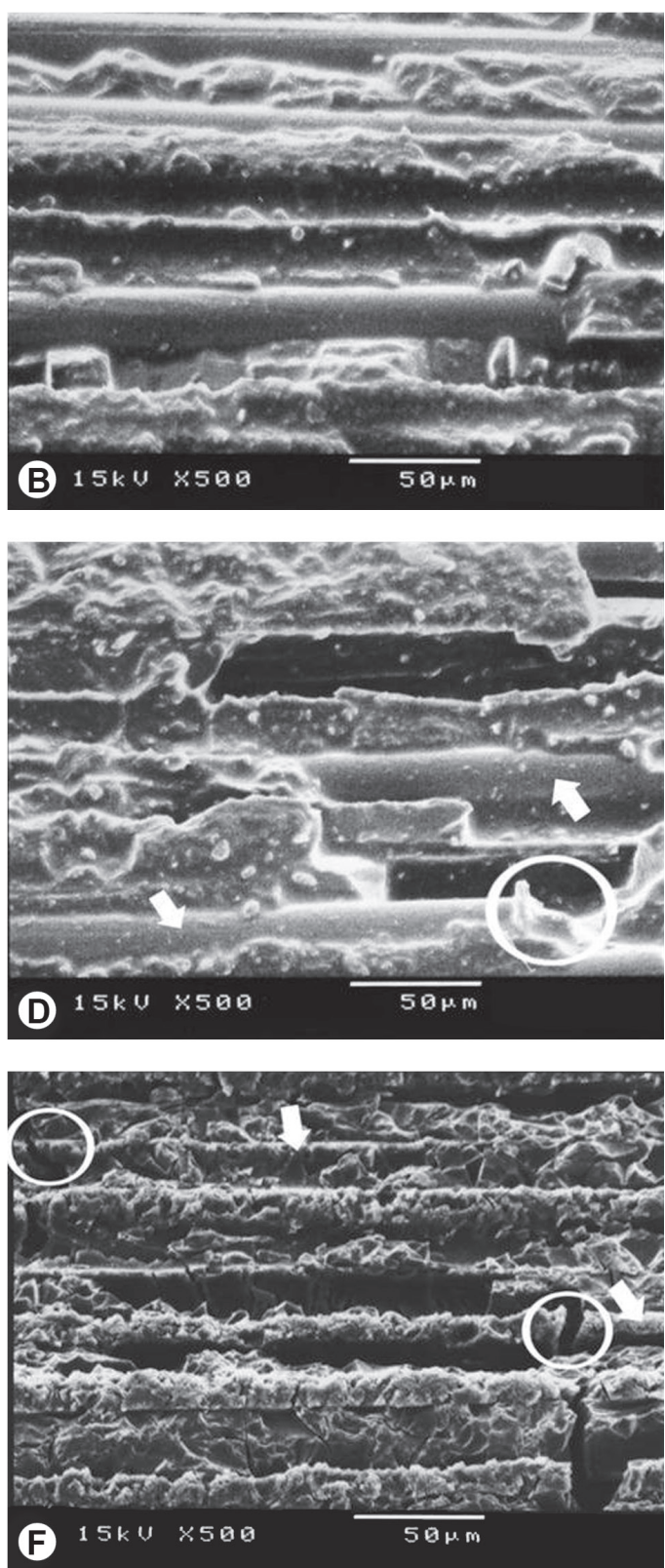

Figure 2. SEM micrographs of the post surfaces after different treatments $(\times 500)$. A: Serrated post treated with $10 \% \mathrm{HP} / 10 \mathrm{~min}$. B: Smooth post treated with $10 \% \mathrm{HP} / 10 \mathrm{~min}$ - slight exposure of the fibers, mostly in smooth posts. C: Serrated post treated with $24 \%$ HP/1 min. D: Smooth post treated with 24\% HP/1 min - degradation of the resin matrix and exposed fibers (arrows). Discontinuous areas on post surface (circles). E: Serrated post treated with $\mathrm{Al}_{2} \mathrm{O}_{3}$. F: Smooth post treated with $\mathrm{Al}_{2} \mathrm{O}_{3}$. Note the exposed fibers (arrows) and discontinuous areas on post surface (circles). 
fracture and esthetics (18). However, the longevity of fiber-reinforced posts restorations depends mainly on the strong bond between resin core material, dentin and post $(4,12,14)$. Different treatments have been proposed to modify the surface of fiber posts in order to improve the adhesive capability as well as the clinical performance of these materials (19).

The results of this study showed that smooth posts had higher flexural strength than serrated posts, although the elastic modulus was similar for both posts, regardless of surface pretreatment they have undergone. A possible explanation for the lower flexural strength obtained by serrated posts can be the configuration of these posts, which promote disruption of longitudinal glass fibers close to the additional retentions (20) and also provide stress concentration in these regions (21). The fact that the post resistance is strongly influenced by the resin matrix fibers, justifies the decrease in flexural strength of serrated posts $(7,22)$.

Regarding the bond strength, it is important to highlight that the methacrylate-based luting agent used in this study has no chemical affinity for the epoxy resin matrix of posts, but has affinity for the glass fibers $(5,11,13,14)$. Therefore, superficial cracks found in the fibers of serrated posts can be a critical point on the post/ resin interface and probably reflected in lower adhesion (20). Authors have investigated different procedures for improving the interfacial bond strength between posts and resin-based materials using chemical and mechanical surface treatments and the benefit of using silane on post surface was confirmed $(6,8)$. Monticelli et al. (6) reported an increased wettability of the fiber post surface after silanization.

In the present study, the flexural strength of fiber-reinforced posts abraded with airborne-particles was superior to those pretreated with $24 \% \mathrm{HP}$ for $1 \mathrm{~min}$, but both treatments were not different from $10 \% \mathrm{HP}$ for 10 min and for the untreated posts (control). HP has the ability to dissolve the resin matrix, breaking the epoxy resin bonds and, consequently, exposing the fibers for silanization $(5,16)$. In this process, only the resin matrix is partially dissolved, which reflects the selectivity of HP $(12,14)$. As the fibers remain unchanged (15), there is no interference on the mechanical properties of the posts, hence resulting in similar values of flexural resistance, regardless the surface treatment. The SEM micrographs of groups pretreated with HP showed areas of partial degradation of the resin matrix.

Overall, the outcome of this study is corroborated by Soares et al. (7) that reported that the airborne-particle abrasion did not influence the flexural resistance of posts. However, in our study, aluminum oxide increased the modulus of elasticity of glass fiber posts. According to Schmage et al. (8), the post diameter was reduced after pretreatment with airborne-particle abrasion. In this study, the protocol used for air-abrasion (particles of $50 \mu \mathrm{m}$, pressure of 2.0 bars for $15 \mathrm{~s}$ and a distance of $10 \mathrm{~mm}$ from the surface) produced undesirable changes in the post shape, reducing its diameter, which were confirmed by measurements in made in the posts treated with airborne-particle abrasion. The reduction of the post diameter is related to the modulus of elasticity, since it is calculated by the equation $\mathrm{E}_{\mathrm{f}}=\mathrm{S} 4 \mathrm{~L} 3 / 3 \pi \mathrm{d} 4$, which shows that this property is inversely proportional to diameter. Thus, the decrease in post diameter would increase the modulus of elasticity (2). HP did not alter the post diameter and therefore did not affect its elastic modulus.

When analyzing the bond strength, it was found that all protocols used in this study increased the bond strength of the post/resin interface. This fact can be confirmed by the analysis of the fractures after mechanical test, which revealed a predominance of adhesive failures in the control and treated groups of in both posts, regardless of the pretreatment. Non-treated fiber-reinforced posts have a smooth surface, which limits mechanical interlocking with resin cements, and purely adhesive failure modes are commonly found at the post-composite resin interfaces $(16,23)$. The increased bond strength of posts treated with HP as compared to untreated corroborates the previous findings $(6,12-14)$. In this study, SEM analysis confirmed the removal of epoxy resin surface, creating microgaps that enabled the retention of the adhesive system.

The increased bond strength by airborne-particles abrasion can be ascribed to the irregularities in the post surface, which increases the contact area and create potential spaces for micromechanical retention of the adhesive system, as observed in other studies $(8,15,16)$.

Among all treatments tested in this study, airborne-particle abrasion was the only method that changed the elastic modulus of posts. Additionally, it is a sensitive technique and requires greater control of the operator. Further studies should be conducted to confirm the non-interference of airborne-particles in the adhesive strength.

The use of HP at high concentration may be a suitable alternative for surface pretreatment of the post 
(12). It was observed, in this study, that the mechanical properties and adhesion of resin to post were not affected by increasing the concentration of HP (from $10 \%$ to $24 \%$ ) and decreasing the exposure time of the post to the solution (from $10 \mathrm{~min}$ to $1 \mathrm{~min}$ ), which could be interesting to reduce the clinical time. However, protocols for the application of HP at different concentrations and exposure times need to be investigated.

\section{RESUMO}

O objetivo deste estudo foi avaliar a influência do pré-tratamento de superfície dos pinos de fibra de vidro na resistência à flexão (RF), módulo de elasticidade (ME) e morfologia, bem como a resistência de união (RU) entre os pinos e o núcleo de preenchimento. Cinqüenta e dois pinos de fibra de vidro (lisos e serrilhados) foram divididos em 4 grupos $(\mathrm{n}=13)$ : sem tratamento (controle), peróxido de hidrogênio a $10 \%$ por $10 \mathrm{~min}$ (HP-10), peróxido de hidrogênio $24 \%$ por 1 min (HP-24) e jato de óxido de alumínio $\left(\mathrm{Al}_{2} \mathrm{O}_{3}\right)$. Para avaliar a $\mathrm{RF}$ e ME, o ensaio de flexão de 3 pontos foi realizado. Três pinos de cada grupo foram examinados em MEV. Resina composta foi utilizada como núcleo de preenchimento e as amostras foram seccionadas para obter palitos de microtração. Os dados foram analisados por ANOVA e teste de Tukey $(\alpha=0,05)$. $\mathrm{Na}$ RF, observou-se diferença estatisticamente significante entre os pinos e tipo de pré-tratamento de superfície $(p<0,05)$, com as maiores médias para os pinos lisos. $\mathrm{Al}_{2} \mathrm{O}_{3}$ proporcionou maior $\mathrm{RF}$ que HP-24. $\mathrm{Al}_{2} \mathrm{O}_{3}$ promoveu maior ME que HP-24 e grupo controle. MEV revelou dissolução parcial da matriz de resina em todos os grupos tratados. Os pinos lisos tiveram a maior RU $(p<0,05)$. Os pinos lisos apresentaram RF e RU superior aos pinos serrilhados $(p<0,05)$. As propriedades mecânicas dos pinos de fibra de vidro e a resistência de união entre os pinos e o material resinoso não foram alterados pelos tratamentos de superfície, com exceção do jato de óxido de alumínio que aumentou o módulo de elasticidade dos pinos.

\section{REFERENCES}

1. Zarone F, Sorrentino R, Apicella D, Valentino B, Ferrari M, Aversa $\mathrm{R}$, et al.. Evaluation of the biomechanical behavior of maxillary central incisives restored by means of endocrowns compared to a natural tooth: a 3D static linear finite elements analysis. Dent Mat 2006;22:1035-1044.

2. Plotino G, Grande NM, Bertini R, Pameijer CH, Somma F. Flexural properties of endodontic post and human root dentin. Dent Mat 2007;23:1129-1135.

3. Novais VR, Quagliato BS, Bona AD, Correr-Sobrinho L, Soares CJ. Flexural modulus, flexural strength and stiffness of fiberreinforced post. Indian J Dent Res 2009;20:277-281.

4. Giachetti L, Scaminaci Russo D, Baldini M, Bertini F, Steier L, Ferrari M. Push-out strength of translucent fibre posts cemented using a dual-curing technique or a light-curing self-adhering material. Int Endod J 2012;45:249-256.

5. Goracci C, Raffaelli O, Monticelli F, Balleri B, Bertelli E, Ferrari $\mathrm{M}$. The adhesion between prefabricated FRC posts and composite resin cores: microtensile bond strength with and without post- silanization. Dent Mat 2005;21:437-444.

6. Monticelli F, Toledano M, Tay FR, Cury AH, Goracci C, Ferrari M. Post-surface conditioning improves interfacial adhesion in post/ core restorations. Dent Mat 2006;22:602-609.

7. Soares CJ, Santana FR, Pereira JC, Araujo TS, Menezes MS Influence of airborne-particle abrasion on mechanical properties and bond strength of carbon/epoxy and glass/bis-gma fiberreinforced resin post. J Prosthetic Dent 2008;99:444-454.

8. Schmage P, Cakir FY, Nergiz I, Pfeiffer P. Effect of surface conditioning on the retentive bond strengths of fiber-reinforced composite posts. J Prosthetic Dent 2009;102:368-377.

9. Radovic I, Mazzitelli C, Chieffi N, Ferrari M. Evaluation of the adhesion of fiber posts cemented using different adhesive approaches. Eur J Oral Sci 2008;116:557-563.

10. Bitter K, Paris S, Pfuertner C, Neumann K, Kielbassa AM. Morphological and bond strength evaluation of different resin cements. Eur J Oral Sci 2009;117:326-333.

11. Monticelli F, Ferrari M, Toledano M. Cement system and surface treatment selection for fiber post luting. Med Oral Patol Oral Cir Bucal 2008;13:214-221.

12. Monticelli F, Toledano M, Tay FR, Sadek FT, Goracci C, Ferrari M. A simple etching technique for improving the retention of fiber posts to resin composites. J Endod 2006;32:44-47.

13. Vano M, Goracci C, Monticelli F, Tognini F, Gabriele M, Tay FR, et al.. The adhesion between fibre posts and composite resin cores: the evaluation of microtensile bond strength following various surface chemical treatments to posts. Int Endod J 2006;39:31-39.

14. Yenisey M, Kulunk S. Effects of chemical surface treatments of quartz and glass fiber posts on the retention of a composite resin. J Prosthet Dent 2008;99:38-45.

15. D'Arcangelo C, D'Amario M, Prosperi GD, Cinelli M, Giannoni M, Caputi S. Effect of surface treatments on tensile bond strength and on morphology of quartz-fiber posts. J Endod 2007;33:264267.

16. Albashaireh ZS, Ghazal M, Kern M. Effects of endodontic post surface treatment, dentin conditioning, and artificial aging on the retention of glass fiber-reinforced composite resin post. J Prosthet Dent 2010;103:31-39.

17. Cekic-Nagas I, Sukuroglu E, Canay S. Does the surface treatment affect the bond strength of various fibre-post systems to resin-core materials? J Dent 2011;39:171-179.

18. Mair L, Padipatvuthikul B. Variables related to materials and preparing for bond strength testing irrespective of the test protocol. Dent Mat 2010;26:e17-e23.

19. Soares CJ, Valdivia AD, da Silva GR, Santana FR, Menezes M de S. Longitudinal clinical evaluation of post systems: a literature review. Braz Dent J 2012;23:135-140.

20. Love RM, Purton DG. The effect of serrations on carbon fibre posts-retention within the root canal, core retention, and post rigidity. Int J Prosthod 1996;9:484-488.

21. Soares CJ, Castro CG, Santos Filho PF, Soares PV, Magalhães D, Martins LRM. Two-dimensional FEA of dowels of different compositions and external surface configurations. J Prosthod 2009;18:36-42.

22. Schlichting LH, De Andrada MA, Vieira LC, De Oliveira-Barra GM, Magne P. Composite resin reinforced with pre-tensioned glass fibers. Influence of prestressing on flexural properties. Dent Mat 2010;26:118-125.

23. Balbosh A, Kern M. Effect of surface treatment on retention of glass-fiber endodontic posts. J Prosthet Dent 2006;95:218-223.

Received May 4, 2012

Accepted December 4, 2012 